\title{
Sacred sites and state failures: A case study of the Babri Masjid/Ram Temple dispute in Ayodhya.
}

\author{
Prof Peter W Edge \& Dr M.C. Rajan.
}

\begin{abstract}
Conflicts over the ownership, control, and use of sacred sites claimed by multiple religious communities can pose a serious challenge to the state. The ongoing conflict over the Babri Masjid and Ram Temple in Ayodhya, India, has had a strong legal dimension since 1885. A detailed study of the litigation over the site demonstrates a range of state failures: a judicial failure to provide speedy resolution to land-use and ownership claims; an executive failure to enforce such court orders as were made; and a federal failure to exercise control over the state government directly involved in the dispute. These failures led to an ongoing failure to protect the rights of a significant religious minority in India, and the secularism embedded in the Indian Constitution. A consideration of the dispute in Ayodhya indicates, if not necessarily successful strategies to dealing with conflicts over shared sacred sites, at least some of the dangers which need to be avoided.
\end{abstract}

\section{Introduction}

Sacred sites are powerful sites. Often this power is seen as an opportunity, for instance when a sacred site is seen as generator of social capital to combat disadvantage, or a nexus for the delivery of public goods such as aid. Other times, this power is seen as a threat, for instance when a sacred site is seen as a centre for radicalization in the context of counter-terrorism, or a location for denial of state values such as non-discrimination on the grounds of gender. They can also have a potent symbolic power for members of those communities which see them as sacred, as well as others.

Sacred sites are complex sites. As Hayes has demonstrated, the "religious precinct" goes well beyond a particular numinous space, or a "place for worship". 1 A sacred site may be limited to, say, a chapel, but it may cover open spaces, community spaces, and commercial spaces, the understanding of which is shaped by the association with the place for worship.

Sacred sites are human sites. Within a particular religious worldview, a sacred space may exist without human agency or knowledge. We are going to privilege a rather different perspective, which treats sacredness as a human construct. From this perspective "This space is sacred" is shorthand for "This space is sacred to ...". A space may be sacred to

1 S Hayes, "The religious precinct: Setting the scene for equality law in action?", in B Scharffs, JA Maoz, A Wooley (eds.), Freedom from religion: The emerging context, (Springer, New York, forthcoming). 
an individual alone, but law is more frequently engaged in relation to spaces which are sacred to a community - perhaps a small community or family, but in any case a plurality of individuals.

Sacred sites are shared sites. To some extent, every sacred site is a shared site, unless it has meaning only for one other person, who does not have to share it with other interests. Members of a single, cohesive, religious community may need to share it with one another. Many of the best known controversies over sacred sites involve sites claimed by different religious communities - for instance the long going controversies in Israel over the Noble Sanctuary/Temple Mount.2 Controversies can also arise over non-religious sharing - for instance over religious and heritage uses of Stonehenge in the UK. Given the involvement of the state in the use of any space within its territorial jurisdiction, the State also shares in these sacred sites.

In this chapter, we focus on the legal aspects of one extremely long running controversy, albeit not one which has become an international icon:3 the dispute over the Babri Masjid/Ram Temple in Ayodhya, India. In Part II we discuss the context, and history, of the dispute. In Part III we focus on the litigation aspect of the dispute, including discussion of the $21^{\text {st }}$ century judgments by the High Court and Supreme Court. In our conclusion, Part IV, we reflect on broader lessons to be drawn from this case study.

\section{Context and History.}

Ayodhya is a North Indian town situated in the Faizabad district in the state of Uttar Pradesh. It has some connection with every major religion in India.4 However, the important affiliations for our purposes are those that Hindus and Muslims have with the place. 5

For Hindus, Ayodhya existed as a Saivic centre for many centuries, and in the eighteenth century, became a dominant Vaishnavite centre.6 In particular, Ayodhya is seen by Hindus as the birthplace of Hindu god Ram, who went on to rule the kingdom.7 These

\footnotetext{
2 See more generally RE Hassner, War on sacred grounds,(Cornell UP, New York, 2009).

3 D Viejo-Rose, "Destruction and reconstruction of heritage: Impacts on memory and identity", in $\mathrm{H}$

Anheier and YR Istar, Heritage Memory and Identity, (Sage, New York, 2011).

4 KN Panikkar, 'A Historical Overview' in S Gopal (ed), Anatomy of a Confrontation: The Babri MasjidRamjanmabhumi Issue (Viking, New Delhi 1991) 25-6; Hans Bakker, Ayodhya (Institute of Indian Studies, Groningen 1984) 38.

5 For more information on Ayodhya, see S Gopal (ed), Anatomy of Confrontation: Ayodhya and the Rise of Communal Politics in India (Zed, London 1993) and for a contrasting view, K Elst, Ram Janmabhoomi vs Babri Masjid (Voice of India, New Delhi 1990).

6 S Gopal and others, 'The Political Abuse of History: Babri Masjid-Ramjanmabhumi Dispute - An Analysis by Twenty-Five Historians' in AG Noorani (ed), The Babri Masjid Question 1528-2003: 'A matter of National Honour' (Tulika Books, New Delhi 2003) Vol 1, 30.

7 Peter van der Veer, 'Riots and Rituals: The Construction of Violence and Public Space in Hindu Nationalism' in PR Brass (ed), Riots and Pogroms (Macmillan, London 1996) 160.
} 
events in the age of Tretas - the distant past - were followed by a period during which Ayodhya had disappeared. In the present age, the site was located by king Vikramaditya.9 Within Hindu traditional accounts, although not necessarily archaeological or secular historical accounts, he constructed a huge temple on the birth site of Ram, 10 which was then destroyed to allow Muslims to construct Babri Masjid in 1528, thus giving Hindu claims over the site temporal priority.11 From the eighteenth century, Ayodhya was established as a major pilgrim centre in North India,12 and by 1991 Bawa estimated there were six thousand Hindu temples in the area, with most of the trade and employment opportunities serving pilgrims. 13

As with the Hindu narrative, the Islamic narrative of the history of Ayodhya stresses the antiquity of the connection between religion and the site, long before conventional history might do so. Muslims argue that their attachment to Ayodhya dates back to the pre-Islamic period, with the burial of Seth, one of the children of Adam and Eve, at Ayodhya, as well as Noah.14 Both burial sites continue to attract a substantial number of religious visitors. 15 Ayodhya was ruled by Muslim kingdoms from, it is likely, the $11^{\text {th }}$ century. The first Mughal Emperor defeated the ruler of Ayodhya in battle, and his governor built a mosque in Ayodhya in 1528.16 Ayodhya is considered a 'Khurd Mecca' (small Mecca), because of the large number of Muslim holy persons, including sufi saints and other revered religious figures, who are believed to be buried there.

The pre-1528 history of the site, then, differs considerably between the two communities. This is reflected in how they see 1528. Hindu groups, particularly Sangh Parivar 17

\footnotetext{
8 In Hindu cosmology, cosmos passes through cycles within cycles for eternity. The basic cycle is the Kalpa, formed by a thousand Mahayugas. Each Mahayuga is divided into four yugas or ages called Krta, Treta, Dvapara and Kali. Their lengths are respectively 4,800, 3,600, 2,400 and 1,200 'years of the Gods', and each year equals 360 human years. According to Hindu mythology, Rama spent his youth in Ayodhya and was king during the Treta-yuga, thousands of years before our present age, the Kali-yuga. For details, see, AL Basham, The Wonder that was India (Sidgwick \& Jackson Great Civilizations Series, $3^{\text {rd }}$ rev edn, Sidgwick \& Jackson, London 1967) 320-21.

9 A Copley, 'Indian Secularism Reconsidered: From Gandhi to Ayodhya' (1993) 2 Contemporary south Asia 47, 57.

10 R Friedland and R Hecht, 'The Bodies of Nations: A Comparative Study of Religious Violence in Jerusalem and Ayodhya' (1998) 38 History of Religions 101, 106.

11 P van der Veer, 'God Must be Liberated!: A Hindu Liberation Movement in Ayodhya' (1987) 21 Modern Asian Studies 285-6; Vishwa Hindu Parishad Publication, New Delhi

$<$ http://www.vhp.org/englishsite/e.Special_Movements/dRanjanambhumi\%20Muti/historical_legalperspect ive.htm $>$ accessed $08 / 03 / 2018$.

$12 \mathrm{P}$ van der Veer, Gods on Earth: The Management of Religious Experience and Identity in a North Indian Pilgrimage Centre (Athlone, London 1988) 36.

13 M Bawa, 'Scenes From Ayodhya' The Sunday Times of India (New Delhi 3 November 1991) 18. 14 MJ Akhtar, Babri Masjid: A Tale Untold (Genuine, New Delhi 1997)10.

15 T Mahmood, 'Ayodhya, Ram and Islam' in VN Mishra (ed), Ramjanambhoomi Babri Masjid: Historical documents, Legal opinions and Judgements (The Bar Council of India Trust, New Delhi 1991) 24-25.

16 MJ Akhtar, Babri Masjid: A Tale Untold (Genuine, New Delhi 1997)11.

17 Sangh means organizations and Parivar means family. Sangh Parivar means 'Family of Hindu

Nationalist Organizations' which is an umbrella organization of Hindu nationalist groups.
} 
alleges that the first Mughal Emperor destroyed a magnificent and ancient Ram temple in order to build his Babri Masjid. The Muslim view is that the mosque was built on an empty space, and that there was no evidence of the demolition of a Hindu temple. 18 With the beginning of the direct rule of the area by the British Crown in 1856 the stage was set for these and other community differences to begin to be worked out by litigation.

\section{Litigation, 1856-2018.}

Panikkar traces organisation of the two communities around litigation to the beginning of British rule.19 In 1857, a Hindu priest took a part of the Babri Masjid compound and constructed a chabutra, a raised platform for idols. This was opposed by local Muslims and the dispute was resolved by agreeing to raise a wall between the mosque and the chabutra, which was later called Janmastan temple. However, Muslims made a petition to the local magistrate on 30 November 1858 objecting to the construction of a clay chabutra. The Babri Masjid was officially registered in 1860 as a place of worship for Muslims.20 In 1883-1885 petitions to allow the priest of Janmastan to erect a temple over the chabutra were denied.21 In 1886 the dispute reached the District Court. The judge dismissed the petition on three grounds. Firstly, while it was unfortunate that a masjid had been built on land specially held sacred by the Hindus, as the event occurred 356 years ago it was too late to remedy the grievance. Secondly, any change could cause more harm and derangement of order than benefit. Thirdly, there were no documents to support the claim of the Hindu priest to be the land owner.22 The decision of the District Court was affirmed by the Judicial Commissioner of Avadh, who in his judgement dated 1 November 1886, noted that it was a very wise and proper procedure on the part of the executive and the Civil Courts to have promptly dismissed the plaintiff's claim. The pleas on appeal were wholly unsupported by the facts in the case or by any arguments that appear to be weighty. In addition, there was nothing on the record to show that the plaintiff was the proprietor of the land in question. Hence the appeal was dismissed, and both parties were requested to maintain the status quo.23

An internal dispute between Muslims in 1943-5 was similarly swiftly resolved, with a statutory enquiry finding that the Barbi Masjid was established by a Sunni Muslim, 24 and

18 RS Sharma and others, Ramjanmabhumi-Babari Masjid: A Historians Report to the Nation (People's Publishing House, New Delhi 1991) 6-7.

${ }_{19}$ KN Panikkar, 'A Historical Overview' in S Gopal (ed), Anatomy of a Confrontation (Viking, Delhi

1992) 31-3.

20 MJ Akhtar, Babri Masjid: A Tale Untold (Genuine, New Delhi 1997) 181.

21 Mahant Raghubar Das, Mahant of Janmastan, Ayodhya v The Secretary of State for India in Council, Plaint dated 29 January 1885 - no 61/280 of 1885.

22 Judgement by FEA Chamier, District Judge, Faizabad dated 26 March 1886.

23 Judgement by Judicial Commissioner W Young, Oudh, dated 1 November 1886 in no $1221 \mathrm{~K} / 1886$ cited in AG Noorani (ed), The Babri Masjid Question 1528-2003: A Matter of National Honour (Tulika Books, New Delhi 2003) Vol I, 188.

24 The report of Faizabad District Waqf Commissioner, dated 8 February 1941. 
a later court decision finding that the site was used by both Sunni and Shia Muslims, but was Sunni waqf property.25

In 1949, the controversy took a new turn. During the final months of 1949 a group of sadhus occupied a Muslim cemetery near the mosque, and ignited sacred fires to emphasize their claim that the area was originally a Hindu religious site.26 Some days later, idols of Ram, Lakshman, and Sita, were discovered inside the mosque, Hindus claiming placed there by miraculous means.27 As Gould observes, "this miracle story created a local sensation. Hindus and Muslims flocked to the Janmastan, the former to bear witness to the miracle, the latter to defend the Babri Masjid against desecration and seizure by the Hindus". 28

As the dispute exacerbated local tensions, the local authorities ordered the gates of Babri Masjid to be locked,29 and prohibited both communities from its use, on the basis that the dispute was likely to lead to a breach of the peace. A receiver was appointed to arrange for the care of the property in dispute, and took charge of the disputed property on 5 January 1950. 30 A plethora of suits and counter-suits followed, being consolidated into a single suit in 1964, with the lead suit being a 1961 suit brought by The Sunni Central Board of Waqfs, UP for declaration and recovery of possession of the mosque and graveyard after

25 Shia Central Board of UP Waqf v Sunni Central Board of UP Waqf (1945) Regular Suit no 29/1945.

${ }_{26}$ C Jaffrelot, The Hindu Nationalist Movement and Politics 1925 to the 1990s (Hurst \& Co, London 1996) 93.

27 However, the First Information Report stated: At about 9.00 in the morning around fifty to sixty persons entered the Babri Masjid after breaking open the locks.27 They did not care when Hans Raj, the constable No 70, stopped them from entering. Provincial Armed Constabulary (PAC) guards were called for help but by then the mob had already entered the masjid. Regarding the offenders, Mata Prasad points out that 'Ram Das, Shukla Das, Sudharsan Das with 50 to 60 persons desecrated the mosque by trespassing the mosque through rioting and placing idols in it. AG Noorani, 'Legal Aspects to the Issue' in S Gopal (ed), Anatomy of a Confrontation: The Babri Masjid-Ramjanmabhumi Issue (Viking, New Delhi 1991) 70-1.

28 HA Gould, Grass Roots Politics in India: A Century of Political Evolution in Faizabad District (IBH Publishing Co, Oxford 1994)181-96.

${ }_{29}$ Criminal Procedure Code 1973 (CrPC) (Act No 2 of 1974) s 145 contains an entire chapter on 'disputes as to immovable property'. It reads: (1) whenever a District Magistrate, Sub-Divisional Magistrate or Magistrate of the first class is satisfied from a police-report or other information that a dispute likely to cause a breach of the peace exists concerning any land or water or the boundaries thereof, within the local limits of is jurisdiction, he shall make an order in writing, stating the grounds of his being so satisfied, and requiring the parties concerned in such dispute to attend his court in person or by pleader, within a time to be fixed by such Magistrate, and to put in written statements of their respective claims as respects the fact of actual possession of the subject of dispute, and further requiring them to put in such documents, or to adduce by putting in affidavits, the evidence of such persons, as they rely upon in support of such claims.

Provided further that, if it appears to the Magistrate that any party has within two months next before the date of such order been forcibly and wrongfully dispossessed, he may treat the party so dispossessed as if he had been in possession at such date, Provided also that, if the Magistrate considers the case one of emergency, he may at any time attach the subject of dispute, pending his decision under this section 30 SK Tripati 'One Hundred Years of Litigation' in AA Engineer (ed), Babri Masjid/Ramjanmabhoomi Controversy (Ajanta, New Delhi 1990) 20-1. 
removing the idols and other articles.31 A date was set for the final hearing, but the death of the Receiver in 1970 created a fresh dispute which was only resolved in 1987.32

By the time the substantive action was returned to, however, Ayodhya had begun the process of transformation into a national controversy. 33 In 1984, Vishwa Hindu Parishad, (VHP)34 a Hindu nationalist organisation, initiated a movement to 'liberate' the Ram Janmabhumi and rebuild a magnificent Ram temple at Ayodhya. In 1986 a Hindu intervener who was not a part in any of the main suits secured an order allowing him free entry into the building for prayer, which was not permitted under the interim order of 1950. In his order, Judge K.M. Pandey stated:

After having heard the parties it is clear that the members of the other community, namely Muslims, are not going to be affected by any stretch of imagination if the locks of the gates are opened and the idols inside the premises are allowed to be seen and worshipped by pilgrims and devotees. It is an undisputed fact that the premises are presently in the Court's possession and for the last 35 years Hindus have an unrestricted right of worship as a result of the Court orders of 1950 and 1951 (19.1.50 and 3.3.51). The District Magistrate has stated before me today that members of the Muslim community are not allowed to offer any prayer at the disputed site. If this is the state of affairs, then there is no occasion for law and order problem arising as a result of the removal of locks. It is absolutely an affair inside the premises. 35

The tension among Hindus and Muslims in Ayodhya accelerated when the UP State government acquired 2.77 acres of disputed land on 7 October 1991. 36 The government argued that this was to promote tourism and provide amenities for pilgrims. The acquisition was challenged on the basis that the land was waqf property, and so could not be acquired under the relevant legislation; and that the exercise of power was

31 Regular Suit no 12 of 1961 in the Court of Civil Judge, Faizabad.

32 From the averments of Writ Petition no 746/86 in the Allahabad High Court. For more details, K Prasad and others, Report: Citizen's Tribunal on Ayodhya (The Secretariat, New Delhi 1993) 97-8.

33 DS Burlet, 'Challenging Ethnic Conflict: Hindu-Muslims Relations in India 1977-1993' (PhD Thesis, Department of Peace Studies, University of Bradford 1997) 191.

34 Vishwa Hindu Parishad (VHP) literally means 'World Hindu Council'. As a major component of Sangh Parivar, VHP was founded in 1964. In Hinduism, there existed several sects which represented innumerable rival schools of thought and this division was perceived as the root causes for the weaknesses of Hinduism. The VHP was therefore created to endow Hinduism with a church-like centralized structure and to use this new ecclesiastical apparatus to counter Christian proselyte activities. VHP worked in close association with former rulers, businessmen, respectable politicians and the religious heads of several Hindu sects and monasteries. From 1984, VHP conducted campaigns to liberate sacred sites where Muslim mosques were built in the previous centuries. Particularly, they took up the Babri Masjid -Ramjanmabhumi dispute and claimed the ownership of it to build a Ram temple in its place.

35 Umesh Chandra Pandey v State of UP and Others (1986) Civil Appeal no 66/1986.

36 The Places of Worship (Special Provisions) Act (Act No 42 of 1991) passed in September 1991, would have prevented this, but s.5 explicitly excluded Babri Masjid from its purview (s.5). 
colourable 37 in as much as the real purpose of acquisition was to destroy the mosque and to transfer the land to some Hindu organization to construct a temple thereon. 38 An interim order by the High Court Bench allowed the State to take possession of the land, but ordered that no permanent structure could be erected, and prohibited transfer of the land to any other party. However, through a Deed of Lease on 20 March 1992 between the State government and the Shri Ramjanmabhumi Trust, the land was transferred to the trust against the order of the High Court. In defiance of the court order, the kar sevaks 39 started building a platform on the acquired land, after demolishing existing buildings and temples which clearly violated the status quo order. This was challenged by the Muslims before the court and on 15 July 1992, the Lucknow Bench passed an order stopping any construction activity on the disputed site. On 16 July 1992, the Chief Secretary directed the DM and SSP to ensure compliance with the High Court orders which was defied by the VHP leaders. 40

On 31 October 1992, the Daram Sansad, a religious Parliament of Hindu priests, announced the resumption of kar seva from 6 December 1992.41 The Prime Minister P.V. Narasimha Rao tried to counter the increasing communal tension by making an appeal to the Supreme Court to intervene.42 Subsequently, on 27 November, through an affidavit, the UP State Government assured the Court that they would protect the mosque. The High Court appointed a District Judge as an observer who would report periodically.43 Despite objections by opposing counsel, the Supreme Court in its order of 28 November 1992 permitted Kar Seva as 'a symbolic occasion' while it disallowed any construction work on the acquired 2.77 acres of land. On 30 November 1992, the Supreme Court asked the UP State Government to improve the inadequate security arrangements. However, despite all the assurances from the state government, the Babri Masjid was demolished by the members of Sangh Parivar on 6 December 1992, who built an ad hoc Ram temple in the where Babri Masjid stood earlier.

After the Babri Masjid had been demolished, the Court delivered its judgement in relation to the acquisition of land challenge. The Court found against the UP government on a

37 Justice Krishna Iyer defines colourable legislation as: In the jurisprudence of power, colourable exercise of or fraud on legislative power or, more frightfully, fraud on the Constitution, are expressions which merely mean that the legislature is incompetent to enact a particular law, although the label of competency is stuck on it, and then it is colourable legislation. RS Joshi and others v Ajit Mills Ltd and another; RS Joshi and others $v$ Idar Taluka Sahakari and others (Civil Appeals no 533, 1004, 1410 and 1671-1685 of 1975) AIR 1977 SC 2279.

38 Writ Petition no 3540 (M/B) of 1991 (Civil Miscellaneous Application no 22799 (W) of 1991 and Civil Miscellaneous Application no 22810 (W) 1991.

39 Kar sevak means, 'voluntary laborer', usually in pursuit of a religious objective such as the construction or renovation of a sacred site.

40 K Prasad and others, Report: Citizen's Tribunal on Ayodhya (The Secretariat, New Delhi 1993) 62.

41 'Nothing Can Stop Kar Seva' The Hindu (New Delhi 1 November 1992).

42 ‘Ayodhya: PM Favours Court Arbitration’ The Hindu (New Delhi 15 November 1992).

43 'Observer for Ayodhya' The Hindu (New Delhi 30 November 1992). 
number of grounds, most significantly because the action by the state gave advantage to one party in litigation over the other, contrary to Article 14 of the Constitution, and gave more favourable treatment to one religious group than another, contrary to Article $15(1) .44$

After the demolition, a Writ Petition was filed before the High Court by a lesser known forum called the World Hindu Lawyers Association praying for the darshan of the deity in the makeshift Hindu temple. They requested the court to allow them to exercise their constitutional right to worship,45 and to remove the hurdles for darshan and worship. In their judgment, Justices H.N. Tilhari and A.N. Gupta ordered the relaxation of the orders which were imposed under Section $144 \mathrm{CrPC} 46$ after the demolition. The judges also directed that the state officials allow the petitioners, the Hindus and devotees of Ram to have darshan in the makeshift temple at Ayodhya.47 The judges made their decision in part because an illustrated copy of the Constitution signed by members of India's Constituent Assembly in 1949 contained a picture of the Hindu God Ram.48 The judges found that Ram was therefore 'a constitutional entity' and a 'figure constitutionally accepted as the Lord by the builders of this nation and its culture'.49 The High Court's darshan order was challenged in the Supreme Court which refused to pass any order on the pleas of Muslim organizations to stay the High Court order and directed maintenance of the status quo.50

Although Babri Mosque had now been demolished, in pursuance of the Supreme Court judgment on 24 October 1994, proceedings in the High Court were re-started in January 1996, and continued until judgment by the Allahabad High Court in September 2010. The protracted hearing resulted in three judgments totalling more than 8000 pages.51

All three judges noted the undesirability of the very long period which had passed before the unlocking order of 1986 could be resolved. There was also a willingness to make findings of fact as to the history of the site: Khan $J$ for instance found that the constructed portion of the premises under dispute had been constructed as a mosque under orders of

44 Judgement dated on 11 December 1992 in 'Acquisition of the Land Case'.

45 Indian Constitution art 25.

$46 \mathrm{CrPC}$ (n 103) s 144 grants power to a Magistrate to issue order in urgent cases of nuisance or apprehended danger to life, health or safety, or a disturbance of the public tranquillity, a riot, or an affray. 47 Judgement delivered on 1 January 1993 by Justice HN Tilhari and AN Gupta in Vishwa Hindu Parishad $v$ Union of India case cited in AG Noorani (ed), The Babri Masjid Question 1528-2003: 'A matter of National Honour' (Tulika Books, New Delhi 2003) Vol II, 247-48.

48 H McDonald, 'India: Backlash in Bombay' (January 1993) 21 Far Eastern Economic Review 16, 18. 49 MJ Akhtar, Babri Masjid: A Tale Untold (Genuine, New Delhi 1997) 173.

${ }_{50}$ S Ahmad, 'Judicial Complicity with Communal Violence in India' (1996) 17 Nw J Int'l L \& Bus 320, 334.

51 For a fuller analysis of the decision, see G Arcot Srikantan, "Re-examining secularism: The Ayodhya

Dispute and the equal treatment of religions", (2017) Journal of Law Religion and State 5(2), 117. 
Babar, 52 and that no temple was demolished for its construction. 53 Sharma J, on the other hand, found that such a temple had existed, that it had been destroyed in order to build a mosque and that, under Islamic law, "the disputed structure could not be a mosque as it was raised by force of arms on land belonging to the plaintiff deities". 54

The majority of the Court ruled that the site should be partitioned into three parts roughly 2/3 Hindu, 1/3 Muslim. Khan J stressed sharing of the site between Hindu and Muslim worshippers since pre-1855, and from this found that both communities were in joint possession of the entire premises in dispute, although for convenience they were using and occupying different portions. The three parties (Muslims, Hindus and a named Hindu sect) were declared joint holders until formal partition. Proposals for partition were required within three months, but some areas were set aside for the non-Muslim parties. He was joined by Argawal J, who endorsed the tripartite division, but was more specific about areas set aside for the Hindus. He also stressed the role of the Government of India in making their land available to allow "separate entry ... of the people without disturbing each others rights". The dissenting justice, Sharma J, found that the building was not, under Shariah, a mosque, and that the land remained owned by the Hindu deities in the (pre-existing) Temple. Government attempts to extinguish the sacredness of the place were beyond its competence.

Immediately after the judgement, the Indian Prime Minister appealed for peace, and suggested that the status quo would be maintained until the Supreme Court took up the case. In May 2011 the Supreme Court stayed the verdict, describing it as "strange and surprising". It noted particular that the High Court had granted a relief - partition - which had not been sought by any of the parties. Instead, all parties had sought exclusive rights over the entire precinct. The Supreme Court ordered the status quo, until the case was resolved by the Supreme Court.

In December 2017 the Supreme Court announced that it would begin to hear the civil appeals against the Allahabad High Court judgment in February 2018. In February 2018 the Supreme Court made it clear it would approach the case as a pure land dispute, and accordingly in March 2018 rejected the applications of a significant number of persons wishing to intervene in the case. The Supreme Court began to hear the substance of the case on 23 March 2018.

\section{Analysis.}

\section{The significance of delay..}

52 At p.227.

53 At p.242.

54 At p.14 of 3. 
A key feature of the dispute is the judicial failure to provide a speedy legal resolution to a dispute over the rights over a particular section of space. In particular, for 35 years (1950-1985) the Ayodhya dispute remained a local dispute between a few members of two religious communities. There was no final legal resolution of the dispute before the 1992 demolition, and indeed the Supreme Court did not begin substantive hearings on the case until 2018.

Delay has been described as the 'pathology of the Indian legal system', 55 and has been a longstanding cause of concern.56 Chodosh has suggested that the adversarial model is poorly designed to meet the needs of a rural population with widespread poverty, illiteracy and unfamiliarity with formal legal procedure, particularly since most of it is conducted in the English language, 57 while Deshpande suggest that it creates the opportunity for parties with a weak case to delay resolution against them.58 Average delays in the civil process have been calculated at between ten and fifteen years, 59 and a similar level of delay can be found in cases before the higher judiciary.60

Although delay has been an ever present factor in the Indian legal system, it does not usually exceed ten to fifteen years. However, in the Ayodhya dispute the delay was extended to forty-two years (1950-1992) without even a preliminary trial. The protracted litigation period means that interim relief is of especial importance - interim relief in this case has, literally, spanned generations. The 1950-1 interim relief barred Muslims from Babri Masjid; the 1986 opening of the locks turned the space into place of Hindu public worship.

55 O Mendelsohn, 'The Pathology of the Indian Legal System', (1981) 15 Modern Asian Studies 824.

56 India Civil Justice Committee (1925) Calcutta, Law Commission Report (1958) Fourteenth Report: The Reform of Judicial Administration, New Delhi: Ministry of law and Justice; Law Commission Report (1978) Seventy-Seventh Report: Delay and Arrears in Trial Courts, New Delhi: Ministry of law and Justice; Law Commission Report (1979) Seventy-Ninth Report: Delay and Arrears in High Courts and Other Appellate Courts, New Delhi: Ministry of law and Justice.

57 HE Chodosh and others, 'Indian Civil Justice System Reform: Limitation and Preservation of the Adversarial Process' (1997-1998) 30 NYU J Int'l L \& Pol 1, 25 at 29; see also R Moog, 'Delays in the Indian Courts: Why the Judges Don't Take Control' (1992) 16 Just Sys J 19, 22.

58 VS Deshpande, 'Civil Procedure' in J Minattur (ed), The Indian Legal System (Tripati NM, Bombay 1978) 201. Some of the critical factors involved in delay are: Objections to pecuniary or territorial jurisdiction; Applications for transfer; Pleas of facts; Framing of issues; Preparation of decrees; Failure to scrutinise plaint and appeal; Revision; Death of defendants or respondents; Filing of suits, and appeals for sole purpose of delay; Multiplicity of appeal, and Stays and temporary injunctions.

59 HE Chodosh and others, 'Indian Civil Justice System Reform: Limitation and Preservation of the Adversarial Process' (1997-1998) 30 NYU J Int'l L \& Pol 1, 29. Chodosh and others indicate the time period between the filing of the complaint and the written statement and the framing of the issues by the court averages six to nine months, the taking of evidence takes an average of five years. In the case of appeals, the current backlog is twelve years for interim orders and longer for final dispositions. This may add up to a time period exceeding twenty years for much litigation.

$60 \mathrm{M}$ Kachwaha, The Judiciary in India: Determinants of its Independence and Impartiality (Leiden, Netherlands 1998) 38. 
Thus, this dispute demonstrates how failure to provide a speedy resolution to sacred site disputes can result in exacerbation of communal conflict and denial of human rights. Had the Ayodhya dispute been settled in 1950, it is likely that much of the violence and many of the human rights violations would have been averted. The delay by the courts to adjudicate the title suits for forty two years led to the demolition of the mosque. The postdemolition period, particularly between 6 and 13 December 1992, witnessed serious communal riots, which according to the official records claimed 1,200 lives.61

\section{The importance of the rule of law.}

A recurring feature of the dispute is the unwillingness, or inability, of the executive to enforce the orders of the courts against non-state actors; or indeed a willingness to contravene such orders itself. 62 The clearest example of the latter happened in March 1992. The state government leased out about 42 acres of land in the vicinity of the Babri Masjid complex to the Ram Janmabhumi Nyas (Trust), on perpetual lease, for the implementation of the Ram Story Park project.63 This was in contravention of the court order which stated that the acquired land should not be transferred or alienated. 64

The Indian Constitution created a federal system, based upon a strong union government with state governments that are not sovereign, but which have constitutionally enumerated powers. 65 If the constituent states fail to adhere to the constitutional authority or suffer from internal disturbances, the union government is empowered to use its authority to re-establish democratic rule within that state under Article 356 of the Constitution.66 When the State government of UP violated the provisons of the Indian Constitution, it was open to the union government to implement President's Rule under Article 356 to maintain public order and restore constitutional democracy which includes the rule of law and the protection of secularism. 67 As the 1992 events approached their climax, 'a contingency plan for a take-over of the complex and imposition of President's

${ }_{61}$ C Jaffrelot, The Hindu Nationalist Movement and Politics 1925 to the 1990s (Hurst \& Co, London 1996) 458-64.

62 In Contempt Petition no 97 of 1992 in Writ Petition no 977 and no 972 of 1991.

63 'The deed of Lease dated 20 March 1992 between the UP Government and the Shri Ramjanmabhumi Trust' cited in AG Noorani (ed), Babri Masjid Question 1528-2003: A Matter of National Honour (Tulika Books, New Delhi 2003) 352-61.

64 The Supreme Court order on 15 November 1991 in Writ Petition (C) no 1000/91 with Writ Petition (C) no 977 and no 972 of 1991.

65 Part XI (Articles 245-263) of Indian Constitution delineates the relations between the Union and States. 66 Indian Constitution art 356 confers powers on the President of India to dismiss the duly elected state government if he is satisfied 'on receipt of a report from the Governor of a state or otherwise' that there is a breakdown of constitutional machinery in that state. In the exercise of the emergency powers, however, the role of the governor is crucial.

${ }_{67}$ SR Bommai v Union of India AIR 1994 SC 1918. 
rule was kept ready but there was no clear view within the government on whether the union should get fully involved'.68

Even on 6 December 1992, the union government could have acted and averted the destruction of the mosque. According to the official account, the Home Ministry received information at 12.00 noon about the attack on the Babri Masjid, yet despite this, a Cabinet meeting was only convened at $6.00 \mathrm{pm}$ and President's Rule was proclaimed only at $21.10 \mathrm{pm} .69$ The delay in convening the Cabinet meeting and taking a decision on imposing President's Rule was crucial. The breakdown in the law and order situation allowed for the continued assault and destruction of the Masjid, the clearing of its debris, and work on the building of a platform for the installation of the Ram and other idols. The kar sevaks were therefore given vital time to complete their assault on the Babri Masjid, and to give a wholly new dimension to the problem by building the foundation of the proposed sanctum sanctorum of a Ram Temple.

Thus, legal rights granted to a religious community are insufficient if the state organs are unwilling to use their power to enforce them. The Indian Constitution grants unambiguous legal rights to religious communities, reinforced by specific provision in relation to places of worship in the Indian Penal Code, and the 1991 Protection of Places of Worship Act. Failure of the state organs in enforcing them makes the sacred sites vulnerable to attacks and destruction. The Ayodhya dispute is particularly sobering for the range of state organs which failed to effectively implement legal guarantees. On 6 December 1992, the day of the demolition of the mosque, the Supreme Court itself observed that a grave situation had emerged, where a constitutionally elected government could not discharge sensitive duties in a matter of this magnitude. 70 The statement of V.P. Singh, the former Prime Minister of India, that 'the fall of the three domes of the Babri Masjid were in fact the collapse of the three pillars - Legislature, Judiciary and Executive - of Indian democracy' 71 emphasises that legal rights granted to a religious community are rendered insufficient if the state organs are unwilling to use their power to enforce them.

\section{The importance of, and complexity of, histories.}

A significant form of legitimation of claims by parties competing over Ayodhya has been an appeal to historical fact. As Mehta puts it, "Each of the contending parties, and there

68 M Godbole, Unfinished Innings: Recollections and Reflections of a Civil Servant (Orient Longman, New Delhi 1996) 347.

${ }_{69}$ K Prasad and others, Report: Citizen's Tribunal on Ayodhya (The Secretariat, New Delhi 1994) 84. 70 Legal Correspondent 'UP Government did not discharge its duties' The Hindu (New Delhi 7 December 1992).

71 MJ Akhtar, Babri Masjid: A Tale Untold (Genuine, New Delhi 1997) 202. 
are at least four, evokes the status quo to establish the legitimacy of its claims".72 The status quo is a particular statement of how the site was being used at a particular moment, and clearly had an important function in relation to interim relief. Given the duration of interim relief in this dispute, judicial understanding of the status quo has been of considerable practical significance.

The dispute involves broader entanglements between law and history, however. Writing in 1990, Gopal found that the historical claims by the Muslim and Hindu communities "can find no sanction from history", and stressed that while appropriation of history is a continual process in any society, "in a multi-religious society like ours, appropriations which draw exclusively on communal identities engender endless communal conflicts".73 History, and archaeology, has played a central role in the framing of the legal dispute over ownership and use of the site. 74

The appropriation of history, and debates over historical fact in order to shape contemporary legal and political realities, is by no means restricted to debates with a religious dimension.75 The religious dimension in Ayodhya, however, adds to the complexity. As Mehta puts it, "two temporal registers, asymmetric and incommensurate, are entangled with each other - historic time and mythic time. The first is based on rules of evidence drawn from empirical detail, while the second provides a kind of habit within which belief and faith are mobilised". 76

\section{The difficulty of state neutrality in clashes between minority and majority communities.}

The Preamble of the Indian Constitution defines India as 'a Sovereign, Socialist, Secular, Democratic, Republic.' 77 The framers recognised that in a multi-religious, multi-ethnic country like India, it was essential for religious harmony and for the social fabric of the society that independent India was governed by secular principles. These secular principles were the basis on which the fundamental human rights of all Indian citizens were to be protected, especially those of the minority groups. Protection of minority

\footnotetext{
72 D Metha, “The Ayodhya Dispute: Law's Imagination and the Functions of the Status Quo", in D Mehta and R Roy (eds), Violence and the quest for justice in South Asia, Sage, New Delhi, 2018) at 293.

73 S Gopal et al, "The political abuse of history: Babri Masjid-Rama Janmabhumi Dispute" (1990) Social Scientist 18(1), 76 at 80-1.

74 See S Ratnagar, "Archaeology at the heart of a political confrontation: The case of Ayodhya", (2004) Current Anthropology 45(2), 239.

75 U Belavusau and A Gliszczynska-Grabias (ed), Law and Memory: Towards Legal Governance of History, (CUP, Cambridge, 2017).

76 D Mehta, "The Ayodhya Disputre: The absent mosque, state of emergency and the jural deity", (2015) Journal of Material Culture 20(4), 397 at 398.

77 The word 'Secular' was substituted by the Constitution (Forty-second Amendment) Act, 1976.
} 
rights is embedded in the Constitution and delineated in Articles 2978 and 30.79 The Supreme Court in various cases 80 held that the protection of minorities was supported by the principles of secularism.

In India, the Gandhian understanding of secularism, that all religions should have equal respect, came to dominate legal and political thought in India.81 The meaning of secularism, as contemplated by the Constitution, did not preclude religious protection; rather, it sought to promote religious harmony.82 One distinguishing feature of constitutional secularism in India is the state's promise that it will not identify itself with or be controlled by any single religion. Jacobsohn has defined Indian secularism as 'ameliorative secularism' because it tried to heal some of the inequalities existing in Indian society. 83

The legal dispute in Ayodhya centred on the question of property rights over the site, but became inextricably linked with the differing religious claims which led to continual conflict. Parikh observed that the principle of constitutional secularism permeates the Ayodhya situation, where the religious dispute culminated in a legal action brought by a few Hindus challenging property rights over the disputed site in Ayodhya.84

Subsequent to the Faruqui case, 85 the Court failed to strike down section 7 of the Acquisition of Certain Lands in Ayodhya Act. The majority of judges in this case rejected the argument that Section 7, which in effect permitted the continuance of the puja of the idols, favoured the Hindu community and was anti-secular. Though the majority in the Supreme Court said that the demolition was a 'national shame', it continued to allow worship in the makeshift temple. In this case, the minority judgement rightly held that 'to condone the acquisition of a place of worship in circumstances in

\footnotetext{
78 Indian Constitution art 29: (1) Any section of the citizens residing in the territory of India or any part thereof having a distinct language, script of culture of its own shall have the right to conserve the same. (2) No citizen shall be denied admission into any educational institution maintained by the State or receiving aid out of State funds on grounds of religion, race, caste, language or any of them.

79 Indian Constitution art 30: All minorities, whether based on religion or language, shall have the right to establish and administer educational institutions of their choice.

80 In Re Kerala Education Bill AIR 1958 SC 956, 976-7; Shri Krishna v Gujarat University AIR 1962 Guj 88; DAV College v State of Punjab AIR 1971 SC 1731, 1744.

81 AA Engineer, 'Secularism in India: Theory and Practice' in RC Heredia and E Mathias (eds), Secularism and Liberation (Indian Social Institute, New Delhi 1995) 40.

82 MV Pylee, India's Constitution (Asia Publishing House, London 1962) 123.

83 GJ Jacobsohn, The Wheel of Law: India's Secularism in Comparative Constitutional Context (Princeton University press, Princeton 2003) 94. Jacobsohn defines it as ameliorative since it seeks an amelioration of the social conditions of people long burdened by the inequities of religiously based hierarchies, while embodying a vision of inter-group comity whose fulfilment necessitates cautious deliberation in the pursuit of abstract justice.

84 S Parikh, 'Enshrining a Secular Idol: A Judicial Response to the Violent Aftermath of Ayodhya' (2005)

37 Case W Res J Int'l L 85, 89.

85 Ismail Faruqui v Union of India and Others AIR 1995 SC 605.
} 
which it was demolished is to efface the principle from the Constitution'.86 The Supreme Court also noted that 'the perpetrators of this deed, struck not only against a place of worship, but also at the principles of secularism, democracy and the rule of law enshrined in the Constitution'.87 Yet, despite this recognition the Supreme Court, or for that matter, the High Court, also have failed to restore the site or access to it to the minority community. Parikh argued that the court's definition of secularism contradicted the Indian definition of secularism as 'treating all religions equally'. 88

McHugh states that the disconnection between the language of secularism set out by the Supreme Court and the action actually taken was a result of the court's own biases. $89 \mathrm{He}$ further alleged that 'one aspect of this problem is the continued, practical dominance of members of upper castes within the political, social, economic, and legal institutions of India'.90 Jacobsohn argued in the same manner when he observed 'secularism appears in the form of a radical majoritarian in the service of an assimilationist agenda'.91

Thus, religiously based dispute over a sacred site can be simply one facet of a broader dispute based around community identities.92 Communal violence resulting from the Ayodhya dispute proved to be a turning point in Indian politics which has led to each community having deeply entrenched, polarised political views. The tragedy of the Ayodhya dispute is that it has eroded the belief of communities in the federalist, secular principles enshrined in the Constitution. The political confrontation encouraged religiouscultural confrontation and that in turn strengthens the former.93 Since sacred sites are tied up with the identity of particular communities, any attack on them is seen as an attack on the community and will naturally be defended vigorously. This was demonstrated in the ensuing violence that took place all over India and in the region after the demolition.94

\footnotetext{
86 AG Noorani (ed), Babri Masjid Question 1528-2003: A Matter of National Honour (Tulika Books, New Delhi 2003) Vol II, 271.

87 Ismail Faruqui v Union of India and others AIR 1995 SC 605.

88 S Parikh, 'Enshrining a Secular Idol: A Judicial Response to the Violent Aftermath of Ayodhya' (2005) 37 Case W Res J Int'l L 85, 98.

89 JT McHugh, Comparative Constitutional Traditions (Peter Lang, Oxford 2002) 105.

90 Ibid.

91 GJ Jacobsohn, The Wheel of Law: India's Secularism in Comparative Constitutional Context (Princeton University press, Princeton 2003) 97.

92 Aijaz Ahmad, 'Somnath to Gandhinagar: A Night of Long Knives' in KN Panikkar and S Muralidharan (eds), Communalism, Civil Society and the State: Reflections on a Decade of Turbulence (SAHMAT, New Delhi 2002) 27-9.

93 AA Engineer (ed), Communalism and communal Violence in India: An Analytical Approach to HinduMuslim Conflict (Ajanta, New Delhi 1989) 94-5.

94 Post-Babri Masjid demolition saw Hindu temples being demolished in Pakistan, Bangladesh and in various Arab countries. M Mahmood, 'Backlash to the Destruction at Ayodhya: A View from Pakistan' (1993) 33 Asian Survey 711-21.
} 
Additionally, if a constitutional order uses secular values to protect minorities, undermining secular values can lead to the erosion of the minority rights. In the Ayodhya dispute, it has been shown that the courts continued to support the majoritarian religious community by allowing the Hindus to worship in the Babri Masjid. Throughout the dispute, the judiciary has neglected the principles of secularism and protection of minority rights. Minority communities still view secularism as a guarantee to their fundamental rights; while more broadly the secularism enshrined in the Constitution is seen as the linchpin that binds together all the diverse groups of people within India. As secularism is basic to the Constitution, any attack on a sacred place could be construed as an attack on secularism as established by the Supreme Court in the Bommai case.95 A similar opinion was expressed by Justice Sawanth as, 'the concept of secularism as religious tolerance and equal treatment of all religious groups includes an assurance of the protection of life, property, and places of worship for all religious groups'.96 A failure to deliver these guarantees may, as Justice Ramaswamy points out, result in 'social disunity [which] is bound to corrupt leading to national disintegration.' 97

95 SR Bommai v Union of India (1994) 3 SCC [1].

96 Ibid [149].

97 Ibid [208]. 